\title{
A réz élettani funkciója, a rézfelhalmozódás és a rézhiány kóroktani szerepe ${ }^{*}$
}

\author{
Vetlényi Enikő dr. - Rácz Gergely dr. \\ Semmelweis Egyetem, Általános Orvostudományi Kar, I. Patológiai és Kísérleti Rákkutató Intézet, Budapest
}

\begin{abstract}
A réz esszenciális nyomelem az emberi szervezet számára, fontos szerepet tölt be számos anyagcsere-folyamatban. Nélkülözhetetlen többek között a légzési lánc és a vasanyagcsere helyes múködéséhez, a szabad gyökök eliminációjához, a hormonok, neurotranszmitterek szintéziséhez, valamint az extracelluláris mátrix stabilizálásához. A réz az oxidációs állapotváltozásra képes mivoltának köszönhetően kettős arculatú elem. A jelentősége a szervezetben a fehérjékhez kötötten vitathatatlan, azonban a szabad réz súlyos sejtkárosodást idéz elő főképpen szabad gyökös reakciók, fehérjék egyéb esszenciális fémtartalmának helyettesítése, valamint jelátviteli pályákra gyakorolt változatos hatása révén. Az emberi szervezetben jelen levő réz mennyisége kényes egyensúlyt képez. Mind hiánya, mind többlete súlyos tünetek, illetve kórképek kialakulását idézi elő. Táplálkozáseredetű rézanyagcsere-zavarok ritkán jelentkeznek, mivel az átlagos napi bevitele megfelelően fedezi a szükségletet, valamint a szervezet a rézraktárak kapacitásának köszönhetően jól tolerálja az átmeneti eltéréseket. A hiányállapot és a túlzott bevitel klinikai tüneteinek megismerésében és megértésében a rézanyagcserét érintő genetikai betegségek (Menkes-, Wilson-kór) nyújtottak segítséget. A réznek a krónikus betegségek kialakulásában betöltött szerepére egyre nagyobb figyelem irányul. Jelentősége körvonalazódik neurodegeneratív, valamint daganatos kórképek esetében is, mind kóroki tényezóként, mind terápiás célpontként. Orv Hetil. 2020; 161(35): 1488-1496.
\end{abstract}

Kulcsszavak: réz, szabad gyök, neurodegeneratív betegség, daganat

\section{The physiological function of copper, the etiological role of copper excess and deficiency}

Copper is an essential micronutrient for the human body, taking part in several metabolic processes. It is required for the terminal oxidation, the elimination of free radicals, the proper functioning of iron metabolism, the synthesis of hormones, neurotransmitters and the stabilization of the extracellular matrix. Copper is a two-faced element. Its significance in protein-bounded form is undeniable, but free copper causes severe cell damage mainly through free radical reactions, substituting other essential metals in protein structure, and it has various effects on cell signaling pathways. The amount of copper present in the human body is part of a delicate balance. Both its deficiency and excess can develop severe symptoms and diseases. The nutritional copper balance is rarely broken, because the average daily consumption excessively covers the needs, and the body's copper stores can tolerate the temporary differences. Genetic diseases (Menkes and Wilson disease) helped to understand the copper metabolism and understand the clinical symptoms of deficiency and excessive intake. The role of copper in the development of chronic diseases is receiving increasing attention. Recent studies show its significance in neurodegenerative and cancerous diseases, both in pathogenesis and as a therapeutic target.

Keywords: copper, free radicals, neurodegenerative diseases, tumour

Vetlényi E, Rácz G. [The physiological function of copper, the etiological role of copper excess and deficiency]. Orv Hetil. 2020; 161(35): 1488-1496.

(Beérkezett: 2020. április 16.; elfogadva: 2020. május 20.)

* A Dr. Febér János Emlékére Alapitvány 2020. évi díjazott dolgozata. 


\section{Rövidítések}

$\mathrm{APl}=$ aktivátor protein- 1 ; ATOXl = antioxidáns protein- 1 ; $\mathrm{ATP}=($ adenosine triphosphate $)$ adenozin-trifoszfát; ATP7A $=$ p-típusú ATPáz, Menkes-ATPáz; ATP7B = p-típusú ATPáz, Wilson-ATPáz; cAMP = (cyclic adenosine monophosphate) ciklikus adenozin-monofoszfát $; \mathrm{CBP}=(\mathrm{CRE}$-binding protein $)$ CRE-kötő protein; CRE = cAMP-reszponzív elem; CTRl = (copper transporter 1$)$ réztranszporter- $1 ; \mathrm{DMTl}=($ divalent metal transporter 1 ) divalens fémtranszporter-1; DNS = dezoxiribonukleinsav; EGF = (epidermal growth factor $)$ epidermális növekedési faktor; ERK = (extracellular signal-regulated kinase) extracelluláris szignál szabályozta kináz; FGF = fibroblastnövekedési faktor; HDL = (high-density lipoprotein) magas sürúségú lipoprotein; HIF = hypoxia indukálta faktor; $\mathrm{HRE}=($ hypoxia response element $)$ hypoxia-válaszelem; JNK = C-Jun N-terminális kináz; LDL $=$ (low-density lipoprotein $)$ alacsony sűrűségű lipoprotein; LOX = lizil-oxidáz; NFkB = (nuclear factor kappa-B) nukleárisfaktor-kappa-B; NGF = (nerve growth factor) idegnövekedési faktor; $\mathrm{Nrf2}=$ nuclear factor (erythroid-derived 2)-like 2; p38 = foszfatidil-38-kináz; p53 = tumorszupresszor gén; PAM = peptidil-glicin- $\alpha$-amidáló monooxigenáz; PHD = prolin-hidroxiláz; PI3K = foszfatidilinozitol-3-kináz; SOD = szuperoxid-dizmutáz; STEAP = prosztata hat-transzmembrán epithelialis antigén enzim; TGN = transz-Golgi-hálózat; VEGF = (vascular endothelial growth factor) vascularis endothelialis növekedési faktor; $\mathrm{VHL}=$ Von Hippel-Lindau-fehérje

A réz az átmeneti fémek közé tartozik, a periódusos rendszer 29. eleme. Kétféle oxidációs állapota létezik $\left(\mathrm{Cu}^{+}\right.$, $\left.\mathrm{Cu}^{2+}\right)$. Az emberi szervezet számára esszenciális nyomelem. A homeosztázis fenntartása szempontjából számos kulcsfontosságú metalloprotein alkotóeleme (például citokróm c-oxidáz, szuperoxid-dizmutáz, cöruloplazmin), ezért elengedhetetlen fontosságú többek között a terminális oxidáció és az antioxidáns védelmi rendszer helyes múködéséhez, a vashomeosztázis fenntartásához, hormonok, neurotranszmitterek szintéziséhez, valamint az extracelluláris mátrix stabilizálásához $[1,2]$. Annak ellenére, hogy a réz esszenciális mivolta régóta ismert, még sok a megválaszolatlan kérdés mind az anyagcseréjével, mind annak szabályozásával kapcsolatban. A rézhomeosztázis egyensúlyának megbomlásából adódó veszélyekre a már 1912-ben leírt Wilson-kór és a fél évszázaddal később megismert Menkes-kór hívja fel a figyelmet [3]. Ez a két genetikai betegség kitünően szemlélteti, hogy a réz hiánya és többlete súlyos veszélyforrást jelent a szervezet számára. A rézanyagcserét célzó kutatások jóvoltából egyre több betegség (például neurodegeneratív és daganatos kórképek) patogenezisében merül fel a réz szerepe $[4,5]$. Összefoglaló közleményünk célja a réz emberi szervezetben betöltött szerepének bemutatása, valamint felhívni a figyelmet a rézhomeosztázis-kutatások fontosságára.

\section{A rézhomeosztázis}

A rézhomeosztázis fenntartásának kulcselemei a megfelelő bevitel, felszívódás, a sejten belüli, illetve szervek közti transzport és a kiválasztás. A réz alapvetően táplálék útján jut be az emberi szervezetbe. Az ajánlott napi bevitel felnőttkorban $900 \mu \mathrm{g}$, azonban terhesség ( $1 \mathrm{mg}$ / nap) és szoptatás (1,3 mg/nap) során fokozódik a rézigény [6]. A felnőtt szervezet teljes réztartalma $100 \mathrm{mg}$ ra tehető [7]. Jelentős rézbeviteli forrásnak számító táplálék a csonthéjasok (például kesudió, mandula, pekándió, brazildió, vagy más néven paradió), a máj, a lencse, a borsó, a bab és a tengeri élőlények.

Felszívódása a vékonybél enterocytáin keresztül történik, ahol a réz fóképpen oxidált formában $\left(\mathrm{Cu}^{2+}\right)$ van jelen. Abszorpciója elsősorban a nagy affinitású réztranszporter-1 (CTRl) közremúködésével valósul meg, amit a réz redukciója $\left(\mathrm{Cu}^{+}\right)$előz meg. A redukcióban részt vesz a C-vitamin, valamint különböző reduktáz aktivitású enzimek, például a STEAP és a duodenalis citokróm b [8]. Kisebb mértékben a nem rézspecifikus divalens fémtranszporter-1-nek (DMTl) is szerepe van a felszívódásában, amelynek segítségével a réz(II) is képes a plazmamembránon áthatolni. A citoszolban a szabad rezet a glutation köti meg és osztja szét a különböző szolúbilis rézchaperonok között, amelyek az intracelluláris célfehérjékhez juttatják azt [9]. Az elsősorban antioxidáns tulajdonságairól elhíresült antioxidáns protein-1 (ATOXI) szállítja a rezet a transz-Golgi-hálózathoz (TGN), ahol az ATP7A-n (p-típusú ATPáz, MenkesATPáz) keresztül a Golgi-hálózatba jutva a végső szerkezetük elnyerésére váró cuproenzimekbe épül be. Továbbá az ATP7A a réz megkötését követően szekréciós vesiculum formájában képes lefüződni a TGN-ról, majd a plazmamembránnal fuzionálva a sejtből a keringésbe juttatja a rezet $[8,10]$. A véráramban albuminhoz és $\alpha_{2}{ }^{-}$ makroglobulinhoz (transzkuprein) kötötten szállítódik a portalis keringésen keresztül a rézanyagcsere központi szervébe, a májba. A máj a legfontosabb rézraktár, nélkülözhetetlen szerepet tölt be a réztartalmú fehérjék szintézisében, valamint a réz szervezetből történő eltávolításában. A rézimportereken keresztül (CTRl, DMT1) jut be a májsejtekbe, ahol az ATOXl közvetítésével az ATP7B-n (p-típusú ATPáz, Wilson-ATPáz) keresztül lép be a TGN-ba. Itt nyeri el többek között a fó rézszállító fehérje, a cöruloplazmin a végleges szerkezetét $[11,12]$. A szekretálódó cöruloplazmin az érpályába jutva szállítja a rezet a különböző szervekhez. A rézimporterek múködésének és elhelyezkedésének tekintetében a szervek között számottevő különbség nem ismert, azonban az ATP7A és az ATP7B szempontjából érdekes eltérések figyelhetők meg. Az ATP7A és az ATP7B fehérje expressziója a legtöbb szövetben kimutatható. Kivételt képez a szívizom-, a simaizom- és a zsírszövet. Ez utóbbiban csupán ATP7A lelhető fel, az első kettőben kizárólag ATP7B van [13]. Annak ellenére, hogy mindkét transzporter megtalálható a szervek többségében, funkciójuk szempontjából eltérés észlelhető, amire a hozzájuk kapcsolódó genetikai betegségek (Menkes- és Wilson-kór) hívják fel a figyelmet. Például a bélhámsejtekben és a placentában az ATP7A, a májban, a tejmiri- 


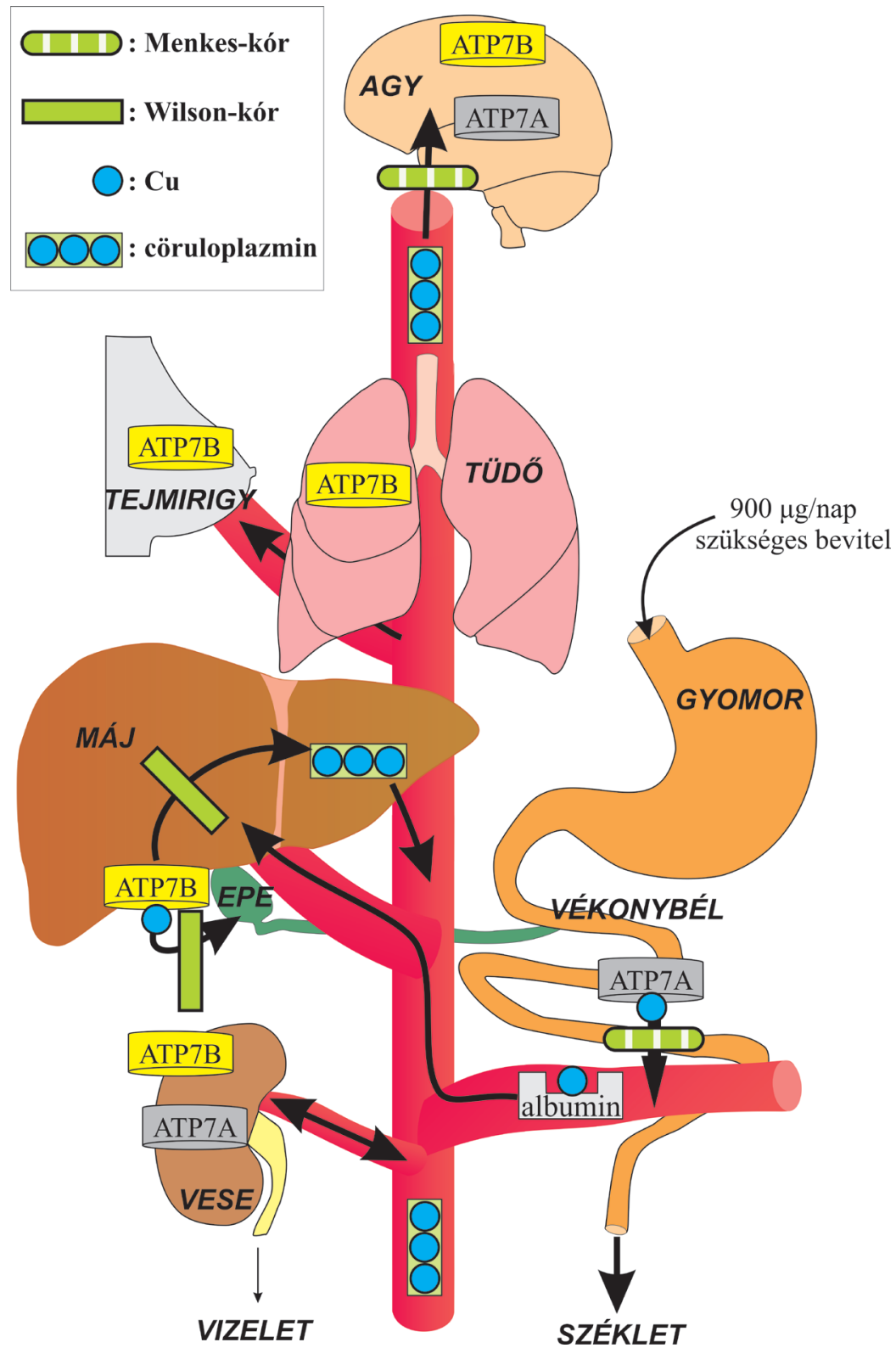

1. ábra

A réz útja az emberi szervezetben és a Menkes- és Wilson-kór okozta réztranszportsérülés legfontosabb pontjai [10, 11]

ATP = adenozin-trifoszfát; ATP7A = p-típusú ATPáz, Menkes-ATPáz; ATP7B = p-típusú ATPáz, Wilson-ATPáz

gyekben és a tüdőben pedig az ATP7B múködése pótolhatatlan, szerepét a másik réz-ATPáz nem helyettesítheti. A mindkét réz-ATPázt tartalmazó szervek esetében az egyes típusok közti szerepmegosztás jelenleg még nem tisztázott [10]. A réz kiválasztása a májban az ATP7B közremúködésével elsősorban az epén keresztül a széklettel, valamint kisebb mennyiségben a vesén át a vizelettel történik [11] (1. ábra).

A réz sejtekbe történő bejutása kevéssé szabályozott folyamat, abszorpciója a szervezet rézigényéhez csekély mértékben alkalmazkodik, azonban más esszenciális fémek anyagcseréjével történő kölcsönhatás befolyásolja felszívódásának a mértékét. A megnövekedett cinkbevitel serkenti a réz- és cinkraktározásra egyaránt alkalmas metallotioneinek szintézisét. Ennek következtében a réz nem jut a keringésbe, hanem a bélhámsejtekben felhalmozódik, és elhalásukat követően a széklettel távozik a szervezetből [14]. A réz abszorpcióját serkentheti például a vashiány, mivel ez esetben a DMTl expressziója növekszik, így több réz felvételére nyílik lehetőség. A rézanyagcsere legszigorúbban szabályozott eleme a kettős szerepet betöltő ATP7A és ATP7B, amelyek segítségével a szervezet alkalmazkodik a sejtek rézigényéhez. A sejten belüli rézkoncentráció-emelkedés következtében a rézATPázok a TGN-ból a plazmamembránba helyeződnek át, és lehetővé teszik a réznek a sejtből történő eltávolítását. Az intracelluláris rézkoncentráció csökkenése a plazmamembránból endocytosissal történő visszavételüket eredményezi, és ismét a cuproenzim-szintézis igényeinek ellátása kerül előtérbe $[10,15]$. 


\section{A réz redox-homeosztázisban betöltött szerepe és a rézproteom legfontosabb elemei}

A redox-homeosztázist az antioxidáns-rendszer és a szabad gyökök egyensúlya határozza meg. A szervezetben fiziológiásan is keletkeznek szabad gyökök (például a mitokondriális elektrontranszportlánc müködése során), eltávolításukat azonban a megfelelően funkcionáló antioxidáns-rendszer hatékonyan képes biztosítani. A redoxhomeosztázis egyensúlyának megbomlása következtében, amit a szabadgyök-termelés fokozódása vagy az antioxidáns-rendszer sérülése okozhat, szabad gyökök szaporodhatnak fel a sejtekben, fehérje- és DNS-károsodást, valamint lipidperoxidációt idézve elő. Ez a folyamat összességében oxidatív stressz kialakulásához vezet, amely számos betegség (például gyulladásos, daganatos, neurodegeneratív betegségek) patogenezisében játszik fontos szerepet $[16,17]$.

A réz érdekes, kettős arculatú elem. Az antioxidánsrendszer hatékony múködéséhez elengedhetetlen fontosságú, azonban a szabad gyökök keletkezését is stimulálhatja. A szervezetben jelen levő szabad réz számottevő veszélyforrást jelent. Redoxváltó képességének köszönhetően részt vesz a Fenton- és a Haber-Weiss-reakcióban, így közvetlenül fokozza a szabad gyökök termelését. A Fenton-típusú reakció során a réz oxidációjának kíséretében jön létre a hidrogén-peroxidból a rendkívül reaktív hidroxilgyök $\left(\mathrm{Cu}^{2+}+\mathrm{H}_{2} \mathrm{O}_{2} \rightarrow \mathrm{Cu}^{+}+-\mathrm{OH}+\mathrm{OH}^{\bullet}\right)$. A többek között a réz által is katalizált Haber-Weiss-reakció eredményeképpen szuperoxid-anionból és hidrogén-peroxidból oxigénmolekula, hidroxilgyök, valamint hidroxilanion keletkezik $\left(\mathrm{H}_{2} \mathrm{O}_{2}+\mathrm{O}_{2}{ }^{-} \rightarrow \mathrm{O}_{2}+-\mathrm{OH}+\right.$ $\mathrm{OH}^{\bullet}$ ) [18].

A rézanyagcserében szerepet játszó fehérjék közül több antioxidáns tulajdonsággal rendelkezik. Az emberi szervezetben háromféle szuperoxid-dizmutáz (SOD) lelhető fel, amelyek közül a SODI és a SOD3 felépítésében a réz és a cink vesz részt [19]. A SOD kulcsfontosságú szerepet tölt be a szuperoxid-anion eliminációjában $\left(2 \mathrm{O}_{2}{ }^{-}+2 \mathrm{H}^{+} \rightarrow \mathrm{H}_{2} \mathrm{O}_{2}+\mathrm{O}_{2}\right)$. Az antioxidáns protein-1 (ATOXI) a nevéhez húen nem csupán rézchaperon, hanem kettős antioxidáns-funkciót is ellát. Az ATOXI a tiolcsoportjai segítségével megköti a glutationtól érkező, valamint a citoszolban szabadon jelen levő rezet. Szintén szabadgyök-eltávolítás kíséri a folyamatot, amelynek során az ATOXl a rezet átadja a Cu-ATPáz-oknak [9]. A rézraktározást szolgáló metallotionein nemcsak a chaperonok által közvetített rezet köti meg, hanem a citoszolból is képes a szabad rezet felvenni [20]. Továbbá az újabb kutatások tanúbizonysága szerint szuperoxid-dizmutáz-aktivitással is rendelkezik [12]. A cöruloplazmin a legfontosabb rézszállító fehérje, a plazma teljes réztartalmának 70-95\%-át köti meg. Ugyanakkor a vasanyagcseréhez is elengedhetetlen fontosságú, mivel ferrooxidáz-tulajdonsággal is rendelkezik. Az érpályába szekretálódó ferrovas $\left(\mathrm{Fe}^{2+}\right)$ ferrivassá $\left(\mathrm{Fe}^{3+}\right)$ történő oxi- dációját katalizálja, ezáltal lehetővé teszi a vas apotranszferrinbe történő beépülését $[12,21]$. A másik réztartalmú ferrooxidáz a hefaesztin, amely a bélhámsejtek basolateralis oldalán helyezkedik el és tölti be a cöruloplazmin esetében is leírt funkciót a vasanyagcserében. A cöruloplazmin és a hefaesztin antioxidáns hatása a ferrooxidáz aktivitásában rejlik, mivel az extracellulárisan megjelenő szabad vasat $\left(\mathrm{Fe}^{2+}\right)$ oxidálja, lehetővé téve a transzferrinhez történő kötődését [21].

Az emberi szervezetben számos, antioxidáns tulajdonsággal nem rendelkező réztartalmú, illetve rézkötő fehérje ismert, amelyek közül csak a legfontosabbakat emeljük ki. A citokróm c-oxidáz a mitokondriális elektrontranszportlánc negyedik komplexe, szerkezetében négy, fémionnal rendelkező centrum található: két vastartalmú, valamint két réztartalmú. Az oxigén vízzé történő átalakulását katalizálja, helyes múködése nélkülözhetetlen a sejtlégzéshez [22]. A lizil-oxidáz (LOX) egy extracelluláris térben elhelyezkedő, rézfüggő amin-oxidáz. Jelentősége az extracelluláris mátrix szerkezetének stabilizálásában rejlik, mivel a kollagén és az elasztin közötti keresztkötések kialakulását katalizálja. Továbbá fontos szerepet tölt be a sejtmigrációban és az angiogenezisben is [23]. A tirozináznak a melanocyták pigmentszintézisében van jelentősége. A dopamin- $\beta$-hidroxiláz egy monooxigenáz, a dopamin noradrenalinná alakulását katalizálja aszkorbát jelenlétében [10]. A peptidil-glicina-amidáló monooxigenáz (PAM) a központi idegrendszerben, az agyalapi mirigyben és a pitvarban helyet foglaló, kettős aktivitású enzim, amelynek múködéséhez réz és aszkorbát szükséges. Jelentősége inaktív peptidhormonok (oxitocin, vazopresszin, gasztrin, kalcitonin, $\alpha$-MSH) és neuropeptidek (substance P, neuropeptid Y) biológiailag aktív formává alakításában rejlik [24]. A legfontosabb réztartalmú fehérjék összefoglalása az 1 . táblázatban olvasható.

\section{A rézhomeosztázis zavarai és a réz kapcsolata különböző betegségek kialakulásával}

\section{Genetikai betegségek}

\section{Wilson-kór}

A Wilson-kór autoszomális recesszíven öröklődő, ritka (1 : 30 000) genetikai betegség. Egyes populációkban azonban megjelenése számottevő, például Szardínia szigetén előfordulási gyakorisága 1 : 7000-re tehető [25]. A Wilson-kór a 13-as kromoszómán található ATP7Bgén mutációja miatt alakul ki. Az ATP7B-génnek több mint 500-féle mutációja ismert, ami a tünetek megjelenésének heterogenitását okozza mind időben, mind a szervek tekintetében [26]. Hazánkban a leggyakrabban a 14-es exonon található H1069Q misszensz mutációja fordul elő [27]. Fontos megjegyezni, hogy heterozigóta-esetekben is jelentkezhet rézfelhalmozódás, és kialakulhatnak klinikai tünetek. 
1. táblázat $\mid$ A legfontosabb réztartalmú, illetve rézkötő fehérjék elhelyezkedése és funkciója

\begin{tabular}{|c|c|c|}
\hline & Elhelyezkedés & Funkció \\
\hline $\begin{array}{l}\text { Szuperoxid- } \\
\text { dizmutáz-1 } \\
\text { (SODl) }\end{array}$ & $\begin{array}{l}\text { Citoplazma, } \\
\text { mitokondrium } \\
\text { intermembrán } \\
\text { tere, } \\
\text { sejtmag }\end{array}$ & $\begin{array}{l}\text { Szabadgyök-detoxifikáció } \\
\left(2 \mathrm{O}_{2}^{-}+2 \mathrm{H}^{+} \rightarrow \mathrm{H}_{2} \mathrm{O}_{2}+\mathrm{O}_{2}\right)\end{array}$ \\
\hline $\begin{array}{l}\text { Szuperoxid- } \\
\text { dizmutáz-3 } \\
\text { (SOD3) }\end{array}$ & $\begin{array}{l}\text { Extracelluláris } \\
\text { mátrix, } \\
\text { endothelsejtek } \\
\text { felszíne }\end{array}$ & $\begin{array}{l}\text { Szabadgyök-detoxifikáció } \\
\left(2 \mathrm{O}_{2^{-}}+2 \mathrm{H}^{+} \rightarrow \mathrm{H}_{2} \mathrm{O}_{2}+\mathrm{O}_{2}\right)\end{array}$ \\
\hline $\begin{array}{l}\text { Antioxidáns } \\
\text { protein-1 } \\
\text { (ATOXl) }\end{array}$ & Citoplazma & $\begin{array}{l}\text { Rézchaperon (ATP7A-hoz és } \\
\text { ATP7B-hez szállítja a rezet) } \\
\text { Antioxidáns } \\
\text { Réz sejtmagba történő } \\
\text { szállítása }\end{array}$ \\
\hline Metallotionein & Citoplazma & $\begin{array}{l}\text { Rézraktározás } \\
\text { (SOD-aktivitás) }\end{array}$ \\
\hline Cöruloplazmin & Vérplazma & $\begin{array}{l}\text { Rézszállítás } \\
\text { Ferrooxidáz }\left(\mathrm{Fe}^{2+} \rightarrow \mathrm{Fe}^{3+}\right)\end{array}$ \\
\hline Hefaesztin & $\begin{array}{l}\text { Bélhámsejt } \\
\text { basolateralis } \\
\text { oldalán }\end{array}$ & Ferrooxidáz $\left(\mathrm{Fe}^{2+} \rightarrow \mathrm{Fe}^{3+}\right)$ \\
\hline $\begin{array}{l}\text { Citokróm } \\
\text { c-oxidáz }\end{array}$ & $\begin{array}{l}\text { Mitokondrium } \\
\text { belső membrán }\end{array}$ & $\begin{array}{l}\text { Légzési lánc enzime, } \\
\text { elektrontranszport } \\
\left(\mathrm{O}_{2} \rightarrow \mathrm{H}_{2} \mathrm{O}\right)\end{array}$ \\
\hline $\begin{array}{l}\text { Lizil-oxidáz } \\
(\mathrm{LOX})\end{array}$ & $\begin{array}{l}\text { Extracelluláris } \\
\text { mátrix }\end{array}$ & $\begin{array}{l}\text { Amin-oxidáz } \\
\text { Extracelluláris mátrix } \\
\text { stabilizációja } \\
\text { (kollagén- és elasztinrostok } \\
\text { keresztkötéseinek kialakítása) }\end{array}$ \\
\hline Tirozináz & $\begin{array}{l}\text { Melanocyta } \\
\text { (szem, bör) }\end{array}$ & $\begin{array}{l}\text { A melaninszintézis elsó } \\
\text { lépése (tirozin } \rightarrow \text { DOPA } \rightarrow \\
\text { dopakinon) }\end{array}$ \\
\hline $\begin{array}{l}\text { Dopamin- } \beta \text { - } \\
\text { hidroxiláz }\end{array}$ & $\begin{array}{l}\text { Noradrenerg } \\
\text { neuron } \\
\text { Mellékvesevelö } \\
\text { kromaffinsejtje }\end{array}$ & $\begin{array}{l}\text { Neurotranszmitter-szintézis } \\
\text { (dopamin } \rightarrow \text { noradrenalin) }\end{array}$ \\
\hline $\begin{array}{l}\text { Peptidil-glicin- } \alpha \text { - } \\
\text { amidáló } \\
\text { monooxigenáz } \\
(\text { PAM })\end{array}$ & $\begin{array}{l}\text { Központi } \\
\text { idegrendszer } \\
\text { Agyalapi mirigy } \\
\text { Szív (pitvar) }\end{array}$ & $\begin{array}{l}\text { Peptidhormonok és } \\
\text { neuropeptidek aktivációja }\end{array}$ \\
\hline
\end{tabular}

ATP = adenozin-trifoszfát; ATP7A = p-típusú ATPáz, Menkes-ATPáz; ATP7B = p-típusú ATPáz, Wilson-ATPáz; DOPA = dihidroxifenilalanin; PAM = peptidil-glicin- $\alpha$-amidáló monooxigenáz

A betegség első tünetei jellemzően 20-30 éves kor körül jelentkeznek, azonban kisgyermekkortól akár 60-70 éves korig is manifesztálódhatnak. A génmutáció következtében a szervezetben funkcióvesztett ATP7B van jelen, amelynek hiánya kiváltképpen a májhoz kapcsolódóan okoz klinikai tüneteket. Az inaktív ATP7B miatt a májsejtekből a réz epén keresztüli kiválasztása gátolt, így a májban jelentős mennyiségben halmozódik fel. Kezdetben a metallotioneinek megkötik a réztöbbletet, azonban kapacitásuk kimerülését követôen a réz szabad gyökös folyamatokon keresztül májkárosodást indukál. Kialakíthat akut vagy krónikus hepatitist, valamint cirr- hosishoz és májelégtelenséghez is vezethet. Az extrahepaticus szövetek közül a leggyakrabban az agy, a vese és a cornea érintett. Az idegrendszeri tünetek tekintetében fóképpen a motoros rendszer eltérései dominálnak. Jellemző a mozgászavar, a tremor, az ataxia, a dystonia, a parkinsonizmus, valamint a beszédzavar. Pszichiátriai tünetek is gyakran jelennek meg, úgymint személyiség- és viselkedésváltozás, szorongás, depresszió, irritabilitás. Szembetúnő klinikai jelenség a corneán megjelenő Kayser-Fleischer-gyưrû́. A vesében felhalmozódó réz tubularis károsodást okozhat. Fehérje-, aminosav-, glükóz-, foszfátvesztés, valamint vesekövesség jelentkezhet. Ritkábban osteoporosis, osteomalacia, arthritis, szív- és érrendszeri elváltozások, bőrpigmentáció, valamint endokrin eltérések is előfordulnak, úgymint cukorbetegség, hypoparathyreosis, amenorrhoea [3, 28, 29]. Diagnosztikájában a klinikai tüneteken túl a szérum cöruloplazmin- és szabadréz-tartalmának vizsgálata, 24 órás vizeletgyúijtésből és májbiopsziából történő réztartalommeghatározás, a szem réslámpával történő vizsgálata (Kayser-Fleischer-gyürü keresése), valamint az ATP7B-t kódoló gén mutációjának keresése nyújt segítséget [30]. A Wilson-kór korai diagnózisa esetén a betegség jól kezelhetó, az irreverzibilis szervi károsodások megelőzhetők. Terápiájának kulcsát a különböző rézkelátorok (D-penicillamin, trientin, tetratiomolibdát), a fokozott cinkbevitel és a rézszegény diéta jelenti [28]. Súlyos májkárosodás esetén a májtranszplantáció az egyetlen esély a beteg gyógyulására.

\section{Menkes-kór}

A Menkes-kór X-kromoszómához kötött, recesszíven öröklődő, az ATP7A-gén mutációja miatt létrejövő, ritka (1 : 100 000-250 000), napjainkban is többnyire halálos kimenetelû́ genetikai betegség. A tünetek kialakulásáért az ATP7A funkciócsökkenése vagy -vesztése a felelős. A vékonybélben a CTRl-en keresztül felszívódó réz a bélhámsejtekben halmozódik fel, mivel múködőképes ATP7A hiányában nem tud a keringésbe jutni. Ennek következtében intestinalis rézfelhalmozódás, a szervezet egészében pedig rézhiány alakul ki. A bélhámsejtekhez hasonlóan a placentában is paradox rézfelhalmozódás észlelhetô, ami magyarázza a már intrauterin korban kialakuló neuronalis fejlődési rendellenességeket. A szervezet rézéhezésének következtében a különböző cuproenzimek szintézise jelentősen csökken, valamint a réz vér-agy-gáton történő átjutása is akadályozott. Mindennek hatása a legkifejezettebben a központi idegrendszerben észlelhetó. A szuperoxid-dizmutáz hiányában felhalmozódó szabad gyökök károsítják az agyszövetet, a PAM nélkül számos neuroendokrin peptid szintézise zavart szenved, ami az idegrendszer fejlődését károsítja. Jellemző tünetei a cerebralis atrophia, demyelinisatio, mentális retardáció, epilepszia, kötőszöveti és érrendszeri rendellenességek, törékeny csontok, töredező, ritka, göndör haj, jellegzetes bőrpigmentáció. A betegség többnyire csecsemő-, esetleg kisgyermekkorban jelentkezik [31, 
32]. Diagnosztikája családi anamnézis hiányában elsősorban a szérum csökkent cöruloplazmin- és -rézkoncentráción alapul. Továbbá a plazma katecholamin-öszszetételének meghatározása (dopamin/noradrenalin arány) és genetikai vizsgálatok nyújthatnak segítséget. Terápiája a rézpótlás (réz-hisztidin, réz-klorid, réz-szulfát stb.), amelynek hatékonysága nagymértékben függ a diagnózis felállításának időpontjától. Kéthetes kor előtt megkezdett terápia esetén van esély az irreverzibilis károsodások megelőzésére [31, 32].

\section{Az ATP7A-transzportert érintő egyéb betegségek}

$\mathrm{Az}$ occipitalis szarv szindrómát (más néven IX. típusú Ehlers-Danlos-szindróma, vagy X-hez kötött cutis laxa) gyakran a Menkes-kór egy kevésbé veszélyes típusaként emlegetik. Kialakulásának oka az ATP7A-gén mutációja, amelynek következtében az ATP7A-nak csak a 20-30\%-a múködőképes. Tünetegyüttesét elsősorban a lizil-oxidáz zavara miatt kialakuló kötőszöveti eltérések uralják, idegrendszeri eltérések ritkán fordulnak elő. A nevét a koponyaalapon történő jellegzetes, ék alakú mészlerakódásról kapta, amely a fejbiccentő izom és a csuklyásizom tapadása között jelenik meg. További jellemző tünetei a laza bőr és ízületek, a durva haj, lágyéksérv, húgyhólyag-diverticulumok, kismértékü izomgyengeség. A betegség gyermekkorban jelentkezik, és megfelelő terápia mellett jó prognózisú [31, 32].

Az ATP7A-hoz kötött distalis mononeuropathiát ugyancsak az ATP7A gén missense mutációja hozza létre. Ez esetben az ATP7A-nak 60-70\%-a funkcióképes. A betegséget a distalis izmok gyengesége, sorvadása, valamint kéz- és lábdeformitások jellemzik. Minden életkorban manifesztálódhat [31, 32].

\section{I. típusú oculocutan albinizmus}

Autoszomális recesszíven öröklődő betegség, amelynek hátterében a tirozináz gén mutációja miatt a tirozináz enzim hiánya áll. Ezért más néven tirozináznegatív oculocutan albinizmusnak is nevezik. A tirozináz enzim hiánya a melaninszintézis elmaradását okoza, szembetûnő klinikai tüneteket hozva létre. A betegekre fehér-rózsaszínű bőr, fehér haj, vörösnek látszó szem jellemző, amit fényérzékenység, gyakran látászavar kísér [25].

\section{Egyéb, a rézanyagcserével összefüggésben álló genetikai betegségek}

$\mathrm{Az}$ acoeruloplasminaemia autoszomális recesszíven öröklődő betegség, amely a cöruloplazmin gén mutációja következtében alakul ki. A cöruloplazmin hiánya elsősorban a vasanyagcsere zavarát okozza, azonban a rézanyagcserére is hatással van. Vasfelhalmozódás figyelhető meg a májban, a hasnyálmirigyben, a retinában és a basalis ganglionokban, rézkoncentráció-csökkenés a szérumban. Jellemző klinikai tünetei a retinadegeneráció, a cukorbetegség és különböző neurológiai tünetek [26]. Az alloalbuminae- miát (más néven bisalbuminaemia) az albumint kódoló gén mutációja hozza létre, amelynek következtében az albumin rézszállító funkciója csökken [25].

\section{Gyermekkori cirrhosisok}

A rézzel összefüggésbe hozható, napjainkban ritkán megjelenő gyermekkori cirrhosisok kóroki tényezői nem tisztázottak. Kialakulásukban vélhetően szerepet játszanak genetikai eltérések, a családfavizsgálatok autoszomális recesszív öröklődésmenetet sejtetnek. Létrejöttükben szerepet játszhatnak a táplálkozási szokások is. A XX. század során széles körben elterjedt volt a réztartalmú konyhai eszközök használata, amelyek jelentősen megnövelték az élelmiszerek (főképpen a tej) réztartalmát $[33,34]$.

Az indiai szubkontinensen a XX. század során a gyermekkori májcirrhosisok egyik leggyakoribb típusa az indiai gyermekkori cirrhosis volt, amely elsősorban 6 hónapos és 4 éves kor között jelentkező, főképpen fiúgyermekeket érintő, súlyos májkárosodással járó, kezelés nélkül halálos kimenetelű betegség. Nyugat-Ausztriában 138 gyermek esetében az előbbihez hasonló megjelenésü kórképet, a tiroli gyermekkori cirrhosist figyelték meg, a nemenkénti eloszlásban azonban nem észleltek különbséget. Az idiopathiás réztoxicosis (más néven nem indiai gyermekkori cirrhosis) szintén fiatalkorban, többnyire 2 éves kor előtt jelentkező, gyors lefolyású, cirrhosissal és májelégtelenséggel járó, ritka - világszerte 30 eset ismert - betegség [33, 34].

\section{Rézhiány és túlzott rézbevitel}

A rézhiány hátterében csökkent rézbevitel vagy megnövekedett rézigény áll. A hiányállapot ritka, mivel az átlagos napi bevitel megfelelően fedezi a szükségletet. A terhesség során a rézigény megnő [7]. Az anya megfelelő rézfogyasztása a magzat fejlődése szempontjából rendkívül fontos, különösen kiemelkedő a 3. trimeszter folyamán, mivel a magzat ekkor alakítja ki rézraktárát [25]. A rézhiány megjelenésének hátterében a leggyakrabban különböző bélbetegségekhez társuló felszívódási zavarok, krónikus hasmenés, túlzott cinkbevitel, elhízást csökkentő mütéti beavatkozások (például gyomorbypassmútét), malnutritio, fogyókúra, nem megfelelő teljes parenteralis táplálás áll $[35,36]$. Tüneteinek spektruma széles: enyhe formáját kismértékú hematológiai eltérések (anaemia, leukopenia) dominálják, míg súlyos esetben a Menkes-kórban leírt tünetek jelentkezhetnek. A rézhiány növeli a szív-ér rendszeri betegségek kialakulásának kockázatát. Növeli a koleszterin- és LDL-szintet, míg a HDL mennyiségét csökkenti. Hozzájárulhat hypertrophiás cardiomyopathia, aortastenosis, szívritmuszavarok, érelmeszesedés, magasvérnyomás-betegség létrejöttéhez $[5,36]$. A rézhiányhoz mindezen felül csökkent immunválasz, lassult sebgyógyulás társul [4]. 
A napi rézbevitel tolerálható felső határértéke 10 mg, amit szokványos táplálkozás esetén ritkán haladunk meg. A krónikus fokozott rézbevitel tünetei a Wilson-kór klinikumára emlékeztetnek $[25,36]$. Gyulladás, fertőzés, cukorbetegség esetén a rézkoncentráció és az akutfázisfehérjék csoportjába is sorolható cöruloplazmin szintje is gyakran emelkedett. Kérdéses, hogy az emelkedett rézkoncentráció a rizikófaktora-e ezen betegségeknek vagy a sejtkárosodás következménye [25].

\section{Neurodegeneratí betegségek}

A réz szerepének felderítése a neurodegeneratív betegségek kialakulásában, illetve progressziójában napjaink intenzíven kutatott témaköre. Jelenleg számos megválaszolatlan kérdés van e tekintetben, ezért a továbbiakban csupán a legfontosabb kapcsolódási pontokat emeljük ki gondolatébresztésként. Az amyotrophiás lateralsclerosis motoneuron-degenerációval járó, halálos kimenetelú kórkép, amelynek familiáris altípusában a SODl-gén funkciónyerő mutációját figyelték meg [19, 37]. A Huntington-kór esetében az agyban gyakran rézfelhalmozódás jelenik meg. A réz vélhetően oxidatív stressz létrehozásával játszik szerepet a neuronkárosodások kialakulásában [38]. Parkinson-kórban jellemző a Lewytestek felhalmozódása, amelyeket a szerkezetükben megváltozott, rézkötő képességgel rendelkező $\alpha$-szinukleinek aggregációja alakít ki. A réz serkenti az $\alpha$-szinuklein aggregációját, továbbá szabadgyök-termeléssel is hozzájárul a betegség progressziójához. [39]. Az Alzheimer-kór esetében a réz $\beta$-amiloid-plakkok kialakulását segítő hatását, valamint a szabad gyökös reakciók fontosságát kell kiemelni [38, 40]. Prionbetegségeknél is jelentős figyelem irányul a réz szerepének felderítésére. A prionok nukleinsavat nem tartalmazó fertőző fehérjék, amelyek nagy affinitással képesek a rezet megkötni, ezzel növelve a prionfehérje ellenállását a proteázokkal szemben, ami fokozott fertőzőképességet okoz $[40,41]$.

\section{Daganatos kórképek}

A réz többféle mechanizmus útján segítheti elő a tumor kialakulását. A szervezetben szabadon megjelenő réz a szabad gyökök mennyiségének növelésével, illetve az antioxidáns-rendszer gátlásával/kimerítésével oxidatív stresszt indukálhat. Továbbá képes a DNS-hez kötődve közvetlen DNS-károsodást okozni [16]. A réz helyettesítheti a daganatképződésben fontos szerepet betöltő molekulák esszenciális fémtartalmát, funkcióvesztést, -változást idézve elő. Például a p53 tumorszuppresszor aktív formája cinket tartalmaz. Amennyiben a cink helyére réz épül be a szerkezetébe, a p53 a funkcióját betölteni nem tudja, és a sejt a kontrollálatlan proliferáció útjára léphet [42]. Mindezen felül fontos kiemelni, hogy a réz közvetlen hatását kimutatták számos jelátviteli pályában szerepet játszó növekedési faktor (NGF, FGF, VEGF, EGF), kináz (PI3K, ERK, JNK, p38) és nukleáris transzkripciós faktor ( $\left.\mathrm{Nrf}_{2}, \mathrm{NF}_{\kappa} \mathrm{B}, \mathrm{APl}\right)$ esetében [43], a pontos hatásmechanizmus azonban kevéssé tisztázott. A réz szerepe a legjobban a hypoxia indukálta faktor (HIF-1)

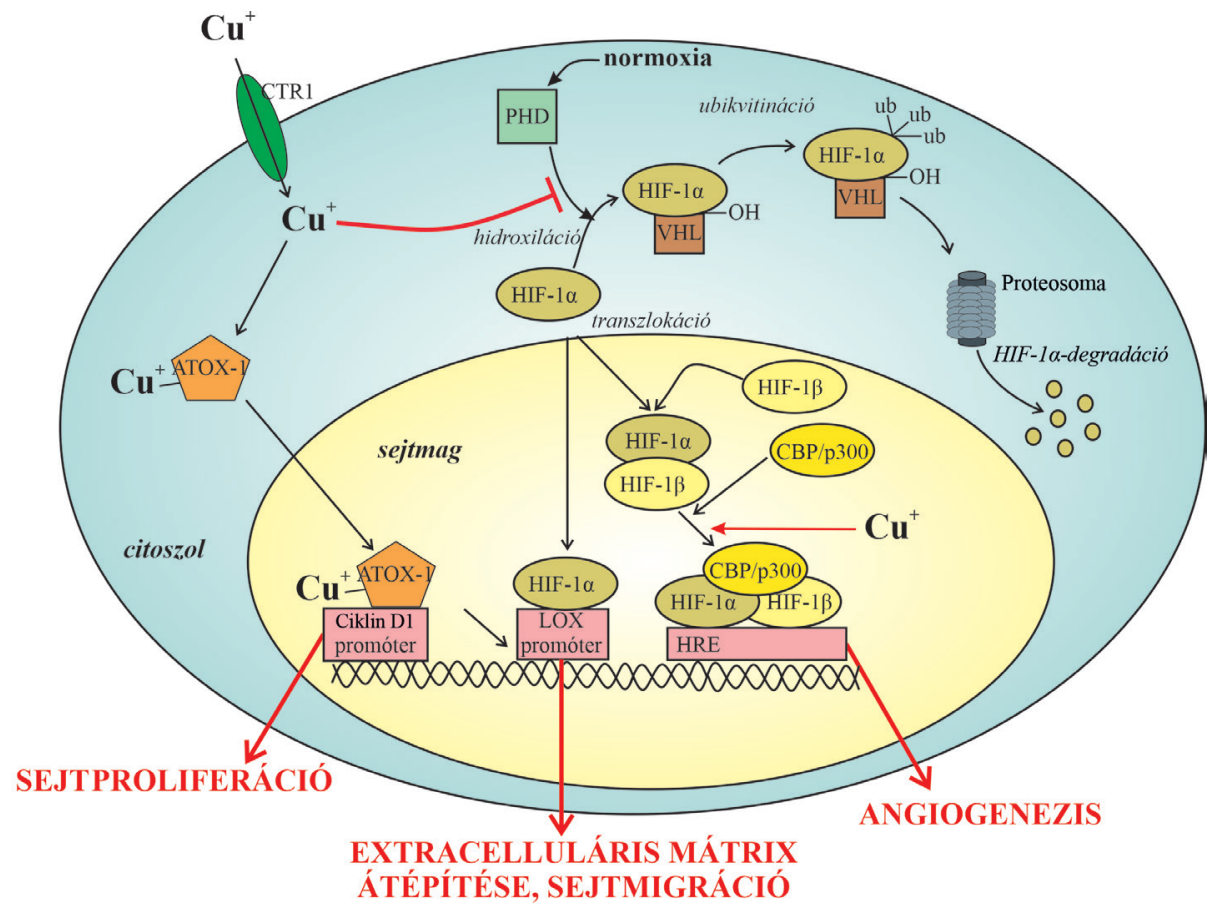

2. ábra $\quad$ A réz hatása a HIF-1 $\alpha$ jelátviteli pályára, valamint az ATOXI segítségével közvetítve a sejtproliferációra [23, 44]

ATOXI = antioxidáns protein- 1 CBP = CRE-kötő protein $; \mathrm{HIF}=$ hypoxia indukálta faktor; HRE = hypoxia-válaszelem; $\mathrm{LOX}=$ lizil-oxidáz; $\mathrm{PHD}=$ prolin-hidroxiláz; VHL = Von Hippel-Lindau-fehérje 
jelátviteli pályájában ismert, amely normoxia esetén a prolin-hidroxiláz (PHD) gátlása alatt áll. A PHD hidroxilálja a HIF-l $\alpha$-t, így elősegíti a Von Hippel-Lindau (VHL) tumorszuppresszor fehérjével történő összekapcsolódását, majd ubikvitinációját, végül a proteosomában történő lebomlását (2. ábra). A réz több ponton képes a HIF-1 $\alpha$ jelátviteli pályát aktiválni normoxia esetén is. Egyrészról a PHD múködését gátolja, ezáltal stabilizálja a HIF-l $\alpha$-t, amely a sejtmagba jutva a HIF-1 $\beta$ val dimerizálódik, és a CBP/p300 kofaktor segítségével a DNS hypoxia-válaszeleméhez (HRE) kötődik [44]. Másrészről a HIF- $1 \alpha-H I F-1 \beta-C B P / p 300$ komplex képződését is serkenti [45]. Így a réz összességében a HRE által kódolt gének, növekedési faktorok, citokinek és extracelluláris mátrixproteázok transzkripcióját indítja el, amelyek az angiogenezist segítik elő. A HIF-l $\alpha$ továbbá a DNS lizil-oxidáz (LOX) promóteréhez is képes kötődni, így az extracelluláris mátrix átépüléséhez, a sejtmigrációhoz, ezáltal a metasztázis kialakulásához járul hozzá [23]. A sejtproliferációt serkentheti továbbá a rezet megkötő ATOXl is, amely a sejtmagba jutva a réz DNS-hez történő kapcsolódását teszi lehetővé, és a ciklin Dl gén indukcióját eredményezi $[44,45]$ (2. ábra).

A réz és a tumor kialakulásának kapcsolata régóta foglalkoztatja a kutatókat. Több daganatos kórkép (lymphomák, bronchialis és laryngealis laphámrák, tüdő-, méhnyak-, emlő-, gyomorrák és colorectalis carcinoma) esetében a szérumban rézkoncentráció-emelkedést figyeltek meg, amely egyes esetekben (például emlőtumor) korrelált a betegség stádiumával, illetve platinatartalmú kemoterápiás szerekkel (például cisz-, carboplatin) szembeni rezisztenciával. Emlö-, colorectalis tumor, lymphoma esetében a szérumhoz hasonlóan a tumorszövetben is növekedett rézkoncentrációt észleltek [46]. Állatkísérletek bizonyítják, hogy a réz nem karcinogén, felhívják azonban a figyelmet arra, hogy a megnövekedett szérum- és szöveti mennyisége hozzájárul a tumor kialakulásához. Továbbá azt sugallják, hogy a tumoros betegek vérében és tumorszövetében megfigyelt rézkoncentráció-emelkedés hátterében a szervezet rézkészletének átrendeződése állhat [47].

A rézkelátorok tumorterápiában történő alkalmazása több mint három évtizede képezi kutatások tárgyát. Több vegyület (d-penicillamin, trientin, tetratiomolibdát) a preklinikai vizsgálatok során ígéretesnek tûnt, a klinikai vizsgálatok azonban nem támasztották alá hatékonyságukat. Más vegyületek (például diszulfirám, kliokinol) tesztelése napjainkban is zajlik új terápiás célpont meghatározása érdekében [48].

\section{Következtetés}

A réz esszenciális mivolta régóta ismert, azonban anyagcseréjének útvonalai, valamint szabályozómechanizmusai még napjainkban is sok megválaszolatlan kérdést vetnek fel. A réznek a neurodegeneratív és a daganatos kórképek kialakulásában, illetve progressziójában játszott szerepére egyre több bizonyíték áll rendelkezésre. A rézhomeosztázis részletesebb felderítése lehetőséget teremthet ezen betegségek patomechanizmusának pontosabb megértésére, valamint új terápiás célpontok megalkotására.

Anyagi támogatás: A közlemény megírása, illetve a kapcsolódó kutatómunka anyagi támogatásban nem részesült.

Szerzôi munkamegosztás: V. E.: A cikk megírása. R. G.: Kritikai észrevételek. A cikk végleges változatát mindkét szerző elolvasta és jóváhagyta.

Érdekeltségek: A szerzőknek nincsenek érdekeltségeik.

\section{Köszönetnyilvánítás}

A szerzók köszönettel tartoznak Dr. Blázovics Annának a cikk megírása során nyújtott segítségéért.

\section{Irodalom}

[1] Bhattacharjee A, Chakraborty K, Shukla A. Cellular copper homeostasis: current concepts on its interplay with glutathione homeostasis and its implication in physiology and human diseases. Metallomics 2017; 9: 1376-1388

[2] Crisponi G, Nurchia VA, Fanni D, et al. Copper-related diseases: from chemistry to molecular pathology. Coord Chem Rev. 2010; 254: 876-889.

[3] Lorincz MT. Wilson disease and related copper disorders. Handb Clin Neurol. 2018; 147: 279-292.

[4] Hordyjewska A, Popiołek $£$, Kocot J. The many "faces" of copper in medicine and treatment. Biometals 2014; 27: 611-621.

[5] Ingle AP, Paralikar P, Shende $S$, et al. Copper in medicine: perspectives and toxicity. In: Rai M, Ingle AP, Medici S. (eds.) Biomedical applications of metals. Springer International Publishing, Cham, 2018; pp. 95-112.

[6] Otten JJ, Hellwig JP, Meyers LD. (eds.) Dietary reference intakes: the essential guide to nutrient requirements. The National Academies Press, Washington, DC, 2006; pp. 304-311.

[7] Bost M, Houdart S, Oberli M, et al. Dietary copper and human health: current evidence and unresolved issues. J Trace Elem Med Biol. 2016; 5: 107-115.

[8] Prohaska JR. Role of copper transporters in copper homeostasis. Am J Clin Nutr. 2008; 88: 826S-829S.

[9] Hatori Y, Lutsenko S. The role of copper chaperone Atoxl in coupling redox homeostasis to intracellular copper distribution. Antioxidants 2016; 5: 25.

[10] Lutsenko S, Barnes NL, Bartee MY, et al. Function and regulation of human copper-transporting ATPases. Physiol Rev. 2007; 87: 1011-1046.

[11] Lalioti V, Muruais G, Tsuchiya Y, et al. Molecular mechanisms of copper homeostasis. Front Biosci (Landmark Ed). 2009; 14: 4878-4903.

[12] Linder MC. Ceruloplasmin and other copper binding components of blood plasma and their functions: an update. Metallomics 2016; 8: 887-905.

[13] The human protein atlas. Available from: https://www.proteinatlas.org/

[14] van den Berghe PV, Klomp LW. New developments in the regulation of intestinal copper absorption. Nutr Rev. 2009; 67: 658672 . 
[15] Kim BE, Nevitt T, Thiele DJ. Mechanisms for copper acquisition, distribution and regulation. Nat Chem Biol. 2008; 4: 176185 .

[16] Reczek CR, Chandel NS. The two faces of reactive oxygen species in cancer. Annu Rev Cancer Biol. 2017; 1: 4.1-4.20.

[17] Liou GY, Storz P. Reactive oxygen species in cancer. Free Radic Res. 2010; 44: 479-496.

[18] Valko M, Jomova K, Rhodes CJ, et al. Redox- and non-redox-metal-induced formation of free radicals and their role in human disease. Arch Toxicol. 2016; 90: 1-37.

[19] Wang Y, Branicky R, Noë A, et al. Superoxide dismutases: Dual roles in controlling ROS damage and regulating ROS signaling. J Cell Biol. 2018; 217: 1915-1928.

[20] Ruttkay-Nedecky B, Nejdl L, Gumulec J, et al. The role of metallothionein in oxidative stress. Int J Mol Sci. 2013; 14: 6044 6066.

[21] Collins JF., Prohaska JR, Knutson MD. Metabolic crossroads of iron and copper. Nutr Rev. 2010; 68: 133-147.

[22] Horn D, Barrientos S. Mitochondrial copper metabolism and delivery to cytochrome c oxidase. IUBMB Life 2008; 60: 421429.

[23] Xiao Q, Ge G. Lysyl oxidase, extracellular matrix remodeling and cancer metastasis. Cancer Microenviron. 2012; 5: 261-273.

[24] Kumar D, Mains RE, Eipper BA. 60 years of POMC: from POMC and $\alpha-\mathrm{MSH}$ to PAM, molecular oxygen, copper, and vitamin C. J Mol Endocrinol. 2016; 56: T63-T76.

[25] The National Academies of Sciences, Engineerig, Medicine. Copper in drinking water. National Academies Press, Washington, DC, 2000. Available from: https://doi.org/10.17226/ 9782

[26] Bandmann O, Weiss KH, Kaler SG. Wilson's disease and other neurological copper disorders. Lancet Neurol. 2015; 14: 103113.

[27] Firneisz G, Lakatos PL, Szalay F, et al. Common mutations of ATP7B in Wilson disease patient from Hungary. Am J Med Genet. $2002 ; 108$ : $23-28$

[28] Roberts EA, Schilsky ML, American Association for Study of Liver Diseases (AASLD). Diagnosis and treatment of Wilson disease: an update. Hepatology 2008; 47: 2089-2111.

[29] European Association for the Study of the Liver. EASL Clinical Practice Guidelines: Wilson's disease. J Hepatol. 2012; 56: 671685 .

[30] Ferenci P. Diagnosis of Wilson disease. In: Członkowska A, Schilsky ML. (eds.) Handbook of clinical neurology. Elsevier, Amsterdam, 2017; Vol. 142, pp. 171-180.

[31] Kaler SG. ATP7A-related copper transport diseases - emerging concepts and future trends. Nat Rev Neurol. 2011; 7: 15-29.

[32] Telianidis J, Hung YH, Materia $S$, et al. Role of the P-type ATPases, ATP7A and ATP7B in brain copper homeostasis. Front Aging Neurosci. 2013; 5: 44 .
[33] Sokol RJ. Copper metabolism and copper storage disorders. In: Suchy F, Sokol R, Balistreri W. (eds.) Liver disease in children. Cambridge University Press, Cambridge, 2014; pp. 465-492.

[34] Tanner MS. Indian childhood cirrhosis and tyrolean childhood cirrhosis. In: Leone A, Mercer JF. (eds.) Copper transport and its disorders. Molecular and cellular aspects. Springer, Boston, MA, 1999; pp. 127-137.

[35] Prohaska JR. Impact of copper deficiency in humans. Ann N Y Acad Sci. 2014; 1314: 1-5.

[36] Osredkar J, Sustar N. Copper and zinc, biological role and significance of copper/zinc imbalance. J Clinic Toxicol. 2011; S3: $1-18$.

[37] Pansarasa O, Bordoni M, Diamanti L, et al. SODl in amyotrophic lateral sclerosis: "ambivalent" behavior connected to the disease. Int J Mol Sci. 2018; 19: 1345.

[38] Desai V, Kaler SG. Role of copper in human neurological disorders. Am J Clin Nutr. 2008; 88: 855S-858S.

[39] Montes S, Rivera-Mancia S, Diaz-Ruiz A, et al. Copper and copper proteins in Parkinson's disease. Oxid Med Cell Longev. 2014; 2014: 147251.

[40] Kozlowski H, Janicka-Klos A, Brasun J, et al. Copper, iron, and zinc ions homeostasis and their role in neurodegenerative disorders (metal uptake, transport, distribution and regulation). Coord Chem Rev. 2009; 253: 2665-2685.

[41] Millhauser GL. Copper binding in the prion protein. Acc Chem Res. 2004; 37: 79-85.

[42] Phatak VM, Muller PA. Metal toxicity and the p53 protein: an intimate relationship. Toxicol Res. 2015; 4: 576-591.

[43] Grubman A, White AR. Copper as a key regulator of cell signalling pathways. Expert Rev Mol Med. 2014; 16: ell.

[44] D'Andrea LD, Romanelli A, Di Stasi R, et al. Bioinorganic aspects of angiogenesis. Dalton Trans. 2010; 39: 7625-7636.

[45] Feng W, Ye F, Xue W, et al. Copper regulation of hypoxia-inducible factor- 1 activity. Mol Pharmacol. 2009; 75: 174-182.

[46] Denoyer D, Masaldan S, La Fontaine S, et al. Targeting copper in cancer therapy: 'copper that cancer'. Metallomics 2015; 7: $1459-1476$

[47] Majumder S, Chatterjee S, Pal S, et al. The role of copper in drug-resistant murine and human tumors. Biometals 2009; 22: 377-384.

[48] Lopez J, Ramchandani D, Vahdat L. Copper depletion as a therapeutic strategy in cancer. Met Ions Life Sci. 2019; 19: 303-330.

(Vetlényi Enikő dr., Budapest, Üllői út 26.; 1085 e-mail: eniko.vetlenyi@gmail.com)

A cikk a Creative Commons Attribution 4.0 International License (https://creativecommons.org/licenses/by/4.0/) feltételei szerint publikált Open Access közlemény, melynek szellemében a cikk bármilyen médiumban szabadon felhasználható, megosztható és újraközölhető, feltéve, hogy az eredeti szerző és a közlés helye, illetve a CC License linkje és az esetlegesen végrehajtott módosítások feltüntetésre kerülnek. (SID_1) 